\title{
Study on Emission and Performance of Diesel Engine Using Castor Biodiesel
}

\author{
Md. Saiful Islam, ${ }^{1}$ Abu Saleh Ahmed, ${ }^{2}$ Aminul Islam, ${ }^{1,3}$ Sidek Abdul Aziz, \\ Low Chyi Xian, ${ }^{2}$ and Moniruzzaman Mridha ${ }^{3}$ \\ ${ }^{1}$ Department of Chemistry, Faculty of Science, Universiti Putra Malaysia (UPM), 43400 Serdang, Selangor, Malaysia \\ ${ }^{2}$ Department of Mechanical and Manufacturing Engineering, Faculty of Engineering, Universiti Malaysia Sarawak, \\ 94300 Kota Samarahan, Sarawak, Malaysia \\ ${ }^{3}$ Research and Development Division, Active Fine Chemicals Ltd., West Mukterpur, Munshiganj 1500, Bangladesh \\ ${ }^{4}$ Department of Physics, Faculty of Science, Universiti Putra Malaysia (UPM), 43400 Serdang, Selangor, Malaysia
}

Correspondence should be addressed to Md. Saiful Islam; msaifuli2007@gmail.com

Received 13 June 2013; Revised 10 November 2013; Accepted 5 December 2013; Published 3 February 2014

Academic Editor: Marcone Augusto Leal de Oliveira

Copyright (c) $2014 \mathrm{Md}$. Saiful Islam et al. This is an open access article distributed under the Creative Commons Attribution License, which permits unrestricted use, distribution, and reproduction in any medium, provided the original work is properly cited.

\begin{abstract}
This paper presents the result of investigations carried out in studying the emission and performance of diesel engine using the castor biodiesel and its blend with diesel from $0 \%$ to $40 \%$ by volume. The acid-based catalyzed transesterification system was used to produce castor biodiesel and the highest yield of $82.5 \%$ was obtained under the optimized condition. The FTIR spectrum of castor biodiesel indicates the presence of $\mathrm{C}=\mathrm{O}$ and $\mathrm{C}-\mathrm{O}$ functional groups, which is due to the ester compound in biodiesel. The smoke emission test revealed that B40 (biodiesel blend with $40 \%$ biodiesel and $60 \%$ diesel) had the least black smoke compared to the conventional diesel. Diesel engine performance test indicated that the specific fuel consumption of biodiesel blend was increased sufficiently when the blending ratio was optimized. Thus, the reduction in exhaust emissions and reduction in brake-specific fuel consumption made the blends of caster seed oil (B20) a suitable alternative fuel for diesel and could help in controlling air pollution.
\end{abstract}

\section{Introduction}

An update on the advances production technique can reinforce the biodiesel as an alternative fuel to combat against global warming. The interest in renewable fuels has increased dramatically in recent years due to high demand of energy and the limitation of fossil fuel [1]. It could offer the opportunities to develop domestic resources in a cost effective manner. Supplementing the petroleum consumption with renewable biomass resources might be one of the components of strategic approach to reduce dependence on petroleum based fuels [2]. Nowadays, the search for alternatives of biofuels is a major environmental and political challenge worldwide. These biofuels can be derived from renewable carbon sources to mitigate greenhouse gas emissions, and the end products can be employed as dropin replacements for petroleum fuels. Furthermore, usage of biodiesel has almost zero emissions of sulfates, a small net contribution of carbon dioxide $\left(\mathrm{CO}_{2}\right)$ when whole lifecycle is considered, and biodiesel is about $10 \%$ oxygen by weight $[3,4]$. Biodiesel is one of the sustainable energies that can be produced from the transesterification process of oils or fats which are from plant or animal with short chain alcohols such as methanol and ethanol as shown in Figure 1 [5].

Biodiesel has become an interesting alternative to be used in diesel engine which is due to the similar properties to the conventional fossil diesel fuel in terms of power and torque and none or very minor of engine modification is required [6]. Moreover, the biodiesel has a few special features which are biodegradability and being much more environmentally friendly compared to the conventional fossil diesel and resulting in less environmental impact upon accidental release to the environment [7]. Although biodiesel has many environmental advantages, it has some drawbacks performance also. The biodiesel behavior is worsening during the cold conditions compared to the fossil diesel fuel. This 

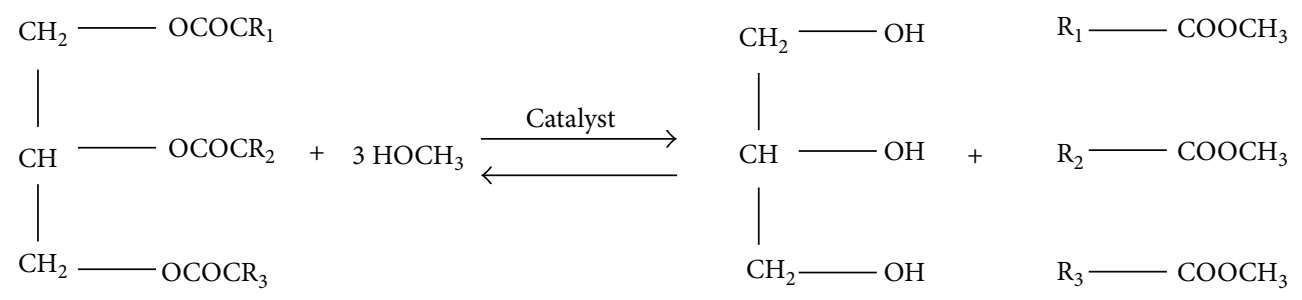

Figure 1

is due to that in low temperature, biodiesel and diesel will form wax crystals that can restrict the flow in a vehicle fuel system clogging fuel lines and filters [8]. The increasing pressure of demand on the use of energy in agricultural, industrial, domestic, and public sectors is an area of concern. Simultaneously, the needs to meet energy demand have created huge capital requirements needed for setting up power plants, pipelines, ports, terminals, and railway tracks to move fuel [9].

Mainly, biodiesel is being produced by the crops like sunflower, soybean, mustard oil, and more in many parts of the world. As the nation is facing a shortage of edible oils, it would not be feasible to produce biodiesel by edible oil. However, first generation technologies have drawbacks in that they rely on feedstocks that are not sufficiently available to satisfy the demands presently met by petroleum, and they rely on easily accessible edible feedstocks fractions, thereby impacting the supply of food for humans and animals. Thus, the utilization of nonedible feedstocks to convert biofuel may be more sustainable strategy to meet the future energy demand. Moreover, the country has enormous potential to produce tree borne oilseeds for biodiesel production to cope with the demand of about $40 \%$ of diesel requirements from total crude oil [10].

The main biodiesel production challenge in commercialization is high cost of production compared to fossil fuel diesel. This is due to that the cost in producing biodiesel is heavily depending on feedstock cost or raw materials $[3,10]$. The higher feedstock production costs are in turn due to high prices of inputs including fertilizer and energy, low recovery of biofuel from feedstock, and availability of a narrow range of inputs for biofuel production [11]. Biodiesel has a very high flash point $\left(300^{\circ} \mathrm{F}\right)$ making it one of the safest of all alternative fuels, from a combustibility point of view. It has a closed carbon cycle $3.2: 1$ production value which is highly efficient [12]. It is noted that biodiesel has a cetane number of over 51 which will make the vehicle perform better in term of fuels ignition with a low idle noise [13]. The most common ratio is $80 \%$ conventional diesel fuel and $20 \%$ vegetable oil ester which is also termed as B20 as indicated by $20 \%$ level of biodiesel. Moreover, consumption of biodiesel blends is only $2-5 \%$ slightly higher than that of conventional diesel fuel [14]. Zhu et al. studied the performance and emissions on Mahua biodiesel blended with ethanol [15]. In their study, they found reduction of $\mathrm{CO}$ and $\mathrm{NO}_{x}$ emissions using $20 \%$ blended fuel but an increase in $\mathrm{HC}$ emission. Hulwan and Joshi reported the performance, emission, and combustion characteristics of a multicylinder diesel engine running on diesel-ethanolbiodiesel blends of high ethanol content [16]. However, there is lack of detailed data on combustion and emission of diesel blended with biodiesel produced from caster seed oil [17]. Thus, the aim of this study is to investigate the combustion, performance, and emissions of a diesel engine operating on diesel-biodiesel blends, using biodiesel produced from caster seed oil.

\section{Material and Methods}

2.1. Materials. Castor seeds were collected from Castor Management, Malaysia. Methanol (Sigma-Aldrich, $\geq 99.8 \%$ ) and potassium hydroxide (Sigma-Aldrich, $\geq 85 \%$ ) were used for transesterification reaction.

2.2. Collection of Crude Castor Oil. The oil extraction was carried out with manual oil expeller having a high pressure continuous screw press and containing a stainless steel helical screw. The extracted oil was kept at room temperature for few hours in order for solids to settle down. The decant oil was then filtered with filter paper (Whatman, Grade 557 1/2) in the force air convection oven with temperature of $80^{\circ} \mathrm{C}$ (boiling point $\left.=313^{\circ} \mathrm{C}\right)$.

2.3. Pretreatment of Crude Coconut Oil. The extracted crude castor oil was filtered and heated to remove unwanted particles in the oil. After filtration, the crude castor oil was then heated to $120^{\circ} \mathrm{C}$ to remove any water content in the oil. Finally, the pretreated crude castor oil was stored in the $500 \mathrm{~mL}$ conical flask sealed with aluminium foil.

\subsection{Measurement of Free Fatty Acid (FFA) in Crude Castor} Oil. The titration method was used to determine the acid value or Free Fatty Acid (FFA) content in the crude castor oil. At first, $10 \mathrm{~mL}$ of $95 \%$ ethanol and $10 \mathrm{~mL}$ of diethyl ether were prepared and poured into the $250 \mathrm{~mL}$ conical flask with 5 drops of phenolphthalein indicator. And then, $50.0 \mathrm{~g}$ of sample of oil was taken into the conical flask and finally titrated with the $\mathrm{KOH}$ solution with continuous stirring to the end point of the indicator where the pink color persisted.

2.5. Transesterification Process (Acid-Based Catalyzed). Acid-catalyzed (sulfuric acid) and based-catalyzed (sodium hydroxide) were conducted to complete the transesterification process. The preheated castor oil was poured into the conical flask containing methanol and then the mixture was 
stirred at $250 \mathrm{rpm}$ and heated continuously for 1 hour. There were 2 methods of heating, namely, direct heating and reflux heating as shown in Figures 2(a) and 2(b). After 1 hour, the mixture was left to settle in the separatory funnel for about 2 hours. Then, 2 layers were found in which upper layer was for methanol-water fraction and the bottom layer for the methyl ester.

2.6. Purification Process. Once the mixture has settled completely, the bottom layer of glycerol was removed. The methyl ester was washed with distilled water to remove impurities such as diglycerine and monoglyceride, catalyst, soap, and excess methanol. Lastly, the biodiesel is kept in a beaker and sealed with aluminium foil to prevent contamination.

2.7. Blending. Collected pure biodiesel is denoted as B100. The blending percentage of biodiesel with diesel was set to $0 \%, 10 \%, 20 \%, 30 \%$, and $40 \%$ and they are mentioned as B0, B10, B20, B30, and B40. All the biodiesel blends were stored in different conical flasks and sealed with aluminium foil for further tests.

2.8. Smoke Emission Test. The smoke emission tests were conducted for all blended fuels. A piece of paper was soaked into the fuel and put into an aluminium container. Then, the paper was burned and emitted smoke which was captured with camera.

2.9. Diesel Engine Test. Diesel engine test was performed using Techno-mate, TNM-TDE-700 machine. The diesel engine testing was done 3 times with each blend of biodiesel and important values such as motor speed, output voltage, output current, and time for $20 \mathrm{~mL}$ fuel flow were recorded. The brake load for the diesel engine testing was fixed at $120 \mathrm{~N}$ and the radius of brake arm was set to $0.5 \mathrm{~m}$.

\section{Results and Discussion}

3.1. Comparison of Biodiesel Yield Percentage with Different Methods. The comparisons of yield percentage between different types of methods used are shown in Table 1. From Table 1, it can be found that the first step with direct heating method obtained highest percentage yield compared to the reflux heating. However, the FFA of methyl ester for direct heating is much higher than the reflux heating method. This is due to the reversible process of acid esterification and high FFA could lead to lower yield of biodiesel in based catalyzed transestnerification. Whereas, highest percentage yield in second step was achieved with orbital shaker method. A significant yield was obtained for second step of based catalyzed transesterification. Therefore, the best method to produce the highest yield percentage of biodiesel is through acid/based catalyzed transesterification with $1: 3$ of oil to methanol ratio for first step with reflux heating and $1: 3$ of oil to methanol ratio with $0.05 \mathrm{~g}$ of $\mathrm{KOH}$ per $20 \mathrm{~mL}$ of oil in the second step with orbital shaker.
TABLE 1: Biodiesel yield percentage in optimum condition for different methods.

\begin{tabular}{lccc}
\hline First step & Percentage yield & Second step & Percentage yield \\
\hline Direct heating & $90 \%$ & Orbital shaker & $67.5 \%$ \\
Reflux heating & $75 \%$ & Orbital shaker & $82.5 \%$ \\
Reflux heating & $75 \%$ & Reflux heating & $57.5 \%$ \\
\hline
\end{tabular}

3.2. FTIR Analysis. In the infrared spectrum of castor biodiesel (Figure 3(a)), the FTIR spectrum of caster diesel showed the alkane $\mathrm{C}-\mathrm{H}$ bond which lies on the wave numbers from $2800 \mathrm{~cm}^{-1}$ to $3000 \mathrm{~cm}^{-1}$ and $1350 \mathrm{~cm}^{-1}$ to $1480 \mathrm{~cm}^{-1}$. Thus, it can be confirmed that both conventional diesel and biodiesel had the same functional group of $\mathrm{C}-$ $\mathrm{H}$ (Figure 3(b)). However, the conventional diesel had no oxygen group, whereas biodiesel showed oxygen functional group such as $\mathrm{C}-\mathrm{O}$ and $\mathrm{C}=\mathrm{O}$ at $400 \mathrm{~cm}^{-1}$ to $1500 \mathrm{~cm}^{-1}$ [18]. Therefore, the biodiesel with the existence of oxygen could be promoted cleaner and complete combustion. On the other hand, the conventional diesel without any oxygen produced more black smoke and incomplete combustion during burning.

3.3. Smoke Emission Test. From the snapshot of few photos which is shown in Figure 4. The black smoke emitted from the diesel burning is much more compared to the B20, B40, and $\mathrm{B} 100$. Anyhow, the black smoke that emitted is reducing from B20 to B100 due to higher biodiesel blend. It is observed that the biodiesel (B100) produced almost no black smoke when it is compared with conventional diesel (B0). On the other hand, the B40 emitted lesser black smoke compared to the B20.

The biodiesel blend produced less black smoke compared to the conventional diesel due to the oxygen content. Moreover, the incomplete combustion of hydrocarbon will produce black smoke too. Thus, the conventional diesel is an incomplete combustion but when it is mixed with biodiesel, the combustion produced is more complete. A complete combustion was obtained with higher biodiesel blend. Hence, the biodiesel blend is much more environmentally friendly compared to the conventional diesel as the biodiesel blend produced less $\mathrm{CO}$ and $\mathrm{CO}_{2}$ and almost zero sulphur emission. Furthermore, the higher cetane number of the biodiesel will lead to lower black smoke emission too. This is explained by the oxygenated nature of biodiesel fuel. Cetane number is an indicator for the fuel in terms of quality. Hence, the higher the cetane number, the better the ignition property of the fuel by producing lesser black smoke [19].

3.4. Engine Performance Testing. Table 2 is the calculation results based on the data collected from diesel engine testing which is ranged from $\mathrm{B} 0$ to $\mathrm{B} 40$. It is observed that the brake horse power, engine power output, and mechanical efficiency are decreasing while the biodiesel blend ratio is increasing. However, the specific fuel consumption increased differently while the biodiesel blend ratio increased. Nevertheless, the engine power output, specific fuel consumption, and mechanical efficiency for every biodiesel blend are plotted 


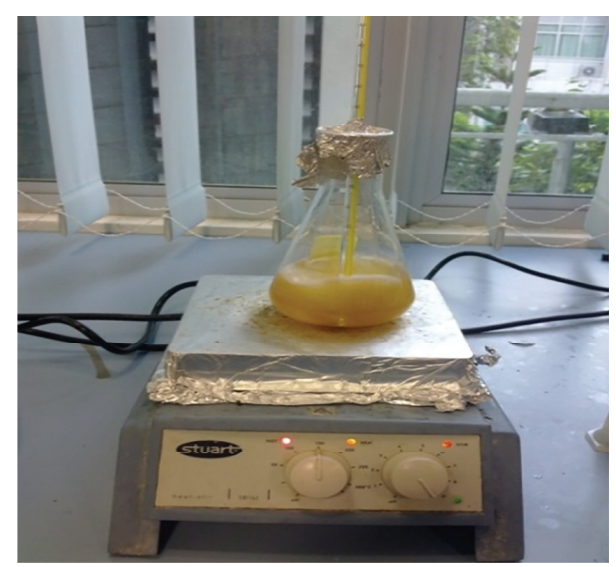

(a)

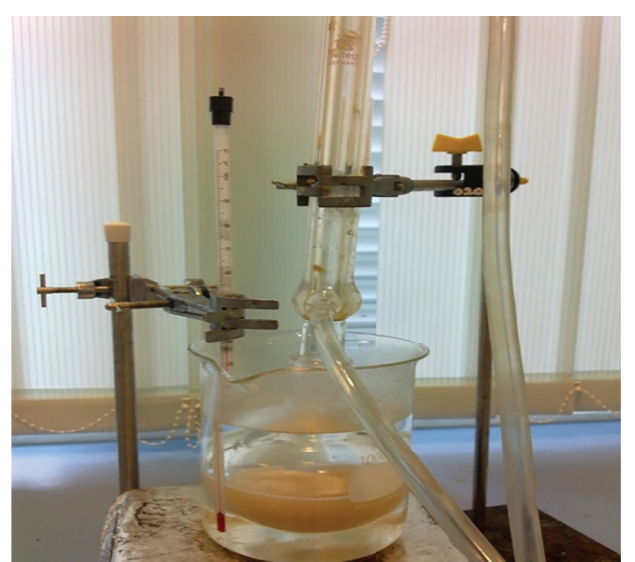

(b)

FIGURE 2: Acid esterification of (a) direct heating and (b) reflux heating.

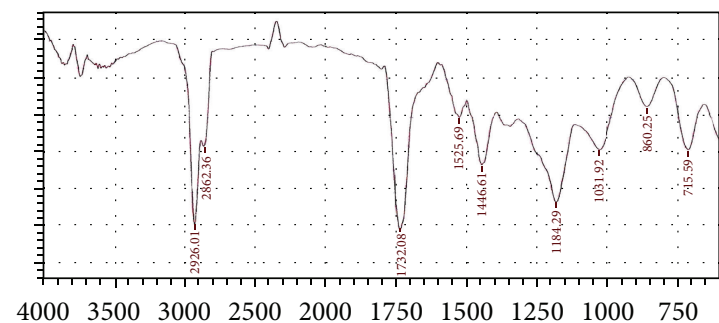

(a)

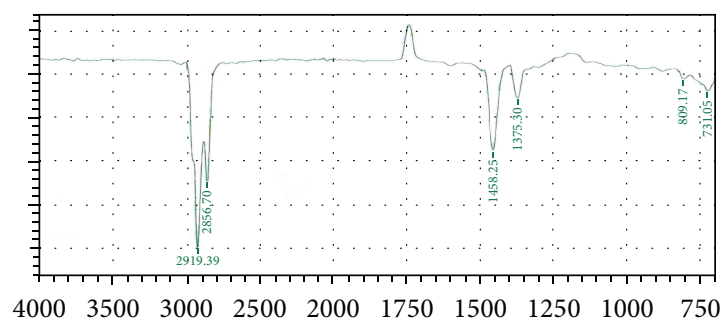

(b)

FIGURE 3: FTIR spectrum of (a) castor biodiesel and (b) conventional diesel.

into a graph for ease of comparison. Based on Figure 4, it is shown that the castor biodiesel blending percentage is inversely correlated to the engine power output. In other words, the engine power output decreased while the castor biodiesel blending percentage increased. The percentage of decrement for $\mathrm{B} 10, \mathrm{~B} 20, \mathrm{~B} 30$, and $\mathrm{B} 40$ relative to $\mathrm{B} 0$ is $0.03 \%$, $0.04 \%, 0.05 \%$, and $0.06 \%$, respectively. From the calculated decrement percentage, it is analyzed that the reduction in engine power output of biodiesel blends is insignificant when compared to the conventional diesel, B0. However, it can be concluded that the low energy content of biodiesel per volume results in the low engine power output.

From Figure 5, it can be observed that the specific fuel consumption is directly correlated to the castor biodiesel blending percentage. In other words, the specific fuel consumption increased when the castor biodiesel blending percentage increased. The increment of the specific consumption of $\mathrm{B} 10, \mathrm{~B} 20, \mathrm{~B} 30$, and $\mathrm{B} 40$ relative to $\mathrm{B} 0$ is $3.59 \%, 3.96 \%$, $4.68 \%$, and $6.23 \%$, respectively. From the increment percentage, it can be spotted that the B40 has the highest SFC value and it consumes more fuel to produce $1 \mathrm{KW}$ of power when compared to conventional diesel (B0). The higher SFC of those higher percentage blends ratio is due to the fact that the biodiesel has lower calorific value than the conventional diesel [20].

Furthermore, higher containments of oxygen in biodiesel are also the cause of the lower calorific value. Despite the better combustion of biodiesel compared to the conventional diesel, the oxygen in biodiesel takes up space in the blend and slightly increases the fuel consumption rate. Thus, higher oxygen content in biodiesel leads to the low calorific value of biodiesel.

On the other hand, the mechanical efficiency is decreasing with the increasing of castor biodiesel blending percentage which is shown in Figure 6. The decrement percentage of mechanical efficiency for B10, B20, B30, and B40 relative to $\mathrm{B} 0$ is $0.085 \%, 0.085 \%, 0.163 \%$, and $0.241 \%$, respectively. From the decrement percentages that were calculated, they obviously shows that the reduction in mechanical efficiency of castor biodiesel blends is insignificant. However, the lower mechanical efficiency of biodiesel is mainly due to the low volatility and high density of ester which affects the automization of the fuel and thus leads to poor combustion [21].

3.5. Emission Analysis. From a study from the United States Environmental Protection Agency (EPA) which has conducted a comprehensive analysis on the emission impacts of biodiesel using the publicly available data, the data was plotted in Figure 7 where the percentage changes of $\mathrm{NO}_{x}$, $\mathrm{PM}, \mathrm{CO}$, and $\mathrm{HC}$ are observed. Figure 8 shows the exhaust emissions of $\mathrm{NO}_{x}, \mathrm{PM}, \mathrm{CO}$, and $\mathrm{HC}$ with varieties of biodiesel blend. It can be observed that $\mathrm{NO}_{x}$ is different from PM, 


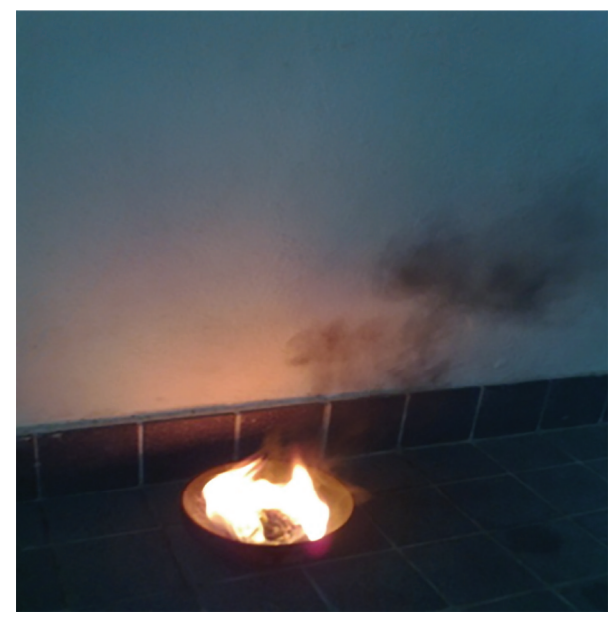

(a)

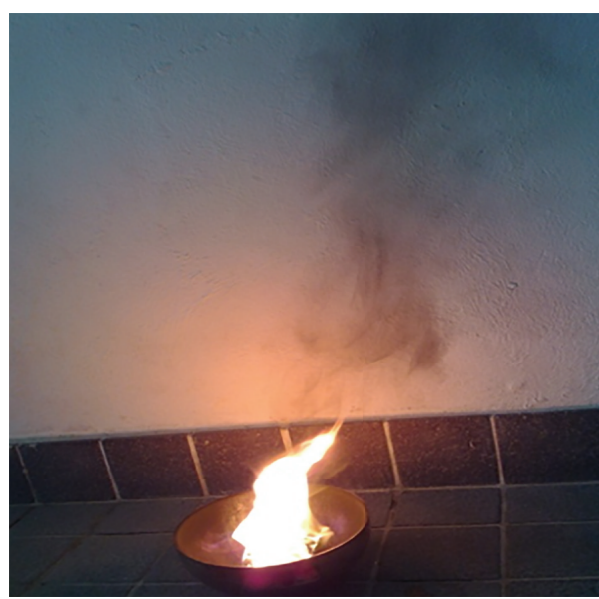

(c)

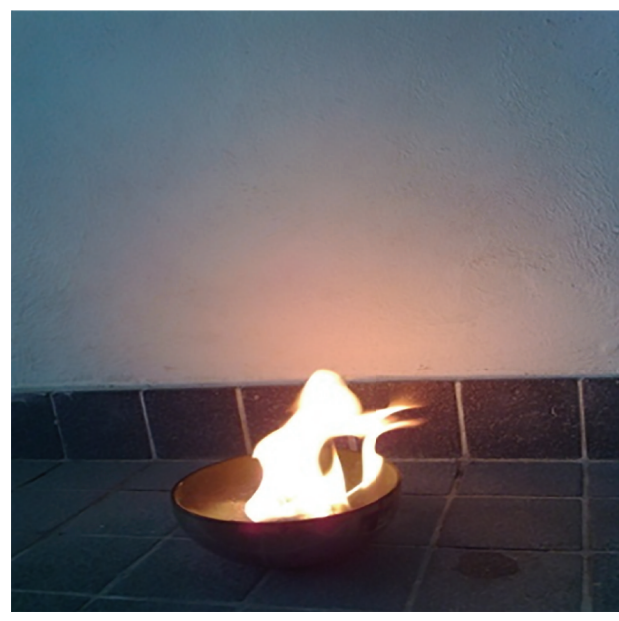

(b)

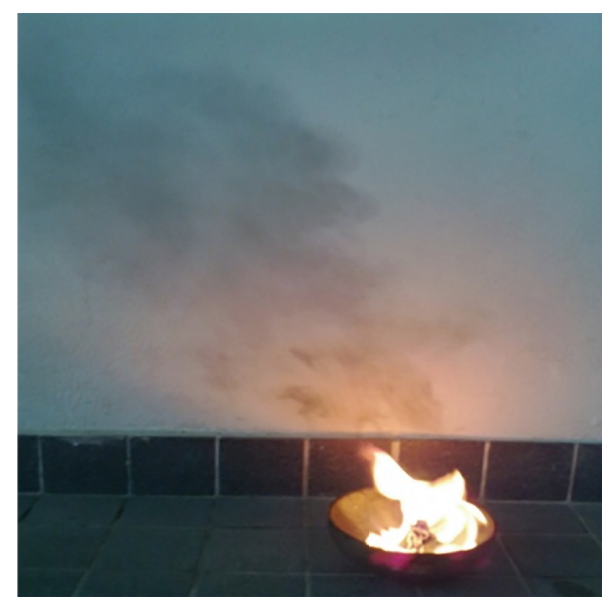

(d)

Figure 4: Burning of (a) B0, (b) B100, (c) B20, and (d) B40.

TABLE 2: Diesel engine testing results for different blends of castor biodiesel.

\begin{tabular}{lccccc}
\hline $\begin{array}{l}\text { Biodiesel } \\
\text { blends }\end{array}$ & $\begin{array}{c}\text { Fuel consumption } \\
\text { rate }(\mathrm{mL} / \mathrm{s})\end{array}$ & $\begin{array}{c}\text { Brake horse power, } \\
\text { BHP (KW) }\end{array}$ & $\begin{array}{c}\text { Engine power } \\
\text { output (KW) }\end{array}$ & $\begin{array}{c}\text { Specific fuel } \\
\text { consumption, SFC } \\
(\mathrm{mL} / \mathrm{KW})\end{array}$ & $\begin{array}{c}\text { Mechanical } \\
\text { efficiency, } \eta(\%)\end{array}$ \\
\hline B0 & 0.247 & 8.156 & 1.358 & 14.728 & 14.111 \\
B10 & 0.241 & 8.149 & 1.311 & 15.256 & 14.099 \\
B20 & 0.242 & 8.149 & 1.306 & 15.311 & 14.099 \\
B30 & 0.249 & 8.143 & 1.288 & 15.418 & 14.088 \\
B40 & 0.242 & 8.137 & 1.278 & 15.645 & 14.077 \\
\hline
\end{tabular}

$\mathrm{CO}$, and $\mathrm{HC}$, where it is increasing with the increasing of percentage ratio of biodiesel, whereas, $\mathrm{PM}, \mathrm{CO}$, and $\mathrm{HC}$ are decreasing with increasing of percentage ratio of biodiesel. Basically, the percentage changes in emissions of $\mathrm{NO}_{x}, \mathrm{PM}$, $\mathrm{HC}$, and $\mathrm{CO}$ for $\mathrm{B} 20$ relative to conventional diesel are $2.0 \%$, $-10.1 \%,-21.1 \%$, and $-11.0 \%$, respectively [22].

The average percentage of change in $\mathrm{NO}_{x}$ emission for $\mathrm{B} 20, \mathrm{~B} 40, \mathrm{~B} 60, \mathrm{~B} 80$, and $\mathrm{B} 100$ that is taken from graph are $2 \%, 4 \%, 6 \%, 8 \%$, and $10 \%$, respectively. This shows that the $\mathrm{NO}_{x}$ emission increased with the increase of percentage ratio of biodiesel. $\mathrm{NO}_{x}$ emission is primarily a function of total oxygen inside the combustion chamber, temperature, pressure, compressibility, and velocity of sound. Invariably biodiesel has some level of oxygen bound to its chemical structures. Thus, oxygen concentration in biodiesel blends fuel might have caused the formation of $\mathrm{NO}_{x}[23,24]$. Furthermore, the increase of $\mathrm{NO}_{x}$ emission is due to the higher cetane number of biodiesel which will reduce the ignition delay. The increase of $\mathrm{NO}_{x}$ emission is a result of the reduced ignition delay [25]. However, the $\mathrm{NO}_{x}$ emissions 


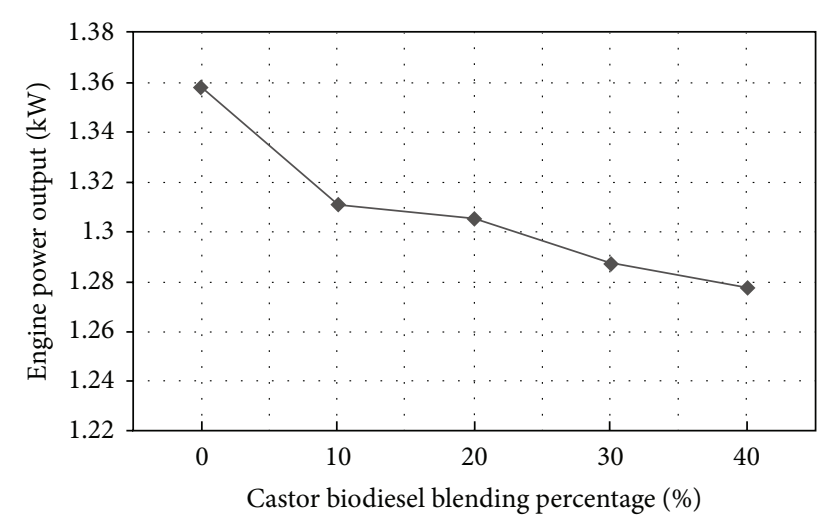

FIGURE 5: Engine power output versus castor biodiesel blending percentage.

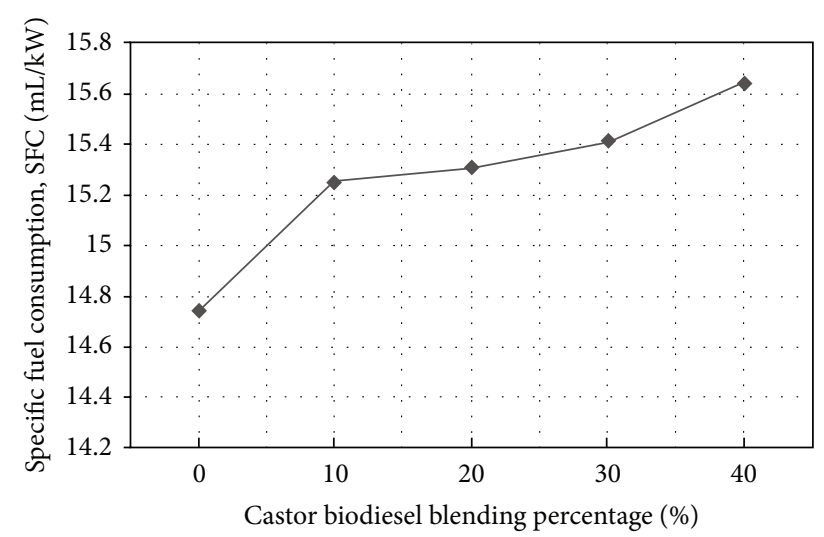

FIGURE 6: Specific fuel consumption versus castor biodiesel blending percentage.

can be reduced through engine tuning or using exhaust catalytic converter $[23,24]$. Moreover, the use of Exhaust Gas Recirculation (EGR) can reduce the $\mathrm{NO}_{x}$ emission too where the temperature of exhaust gas is reduced when passing through the combustion chamber.

Meanwhile, the average percentage of change in PM emission for $\mathrm{B} 20, \mathrm{~B} 40, \mathrm{~B} 60, \mathrm{~B} 80$, and $\mathrm{B} 100$ is $-12 \%,-23 \%,-32 \%$, $-40 \%$, and $48 \%$, respectively. The negative sign is indicating the reduction of the percentage change in emission, whereas the average percentage of change in $\mathrm{CO}$ emission for $\mathrm{B} 20$, $\mathrm{B} 40, \mathrm{~B} 60, \mathrm{~B} 80$, and $\mathrm{B} 100$ is $-13 \%,-24 \%,-33 \%,-40 \%$, and $-48 \%$, respectively. Meanwhile, the average percentage of change in $\mathrm{HC}$ emission for the same biodiesel blends B20, $\mathrm{B} 40, \mathrm{~B} 60, \mathrm{~B} 80$, and $\mathrm{B} 100$ is $-20 \%,-37 \%,-49 \%,-59 \%$, and $-67 \%$, respectively. The reduction of PM and HC is due to the additional oxygen content in the fuel, which helps to oxidize these combustion products and improve combustion in the cylinder [24]. On the other hand, the reduction of $\mathrm{CO}$ and $\mathrm{HC}$ is due to the oxygenated fuel of biodiesel, it leads to a more complete combustion. The higher cetane number of biodiesel fuel reduces delay period leading to lower HC emissions. Thus, the higher oxygen content and cetane number of biodiesel-diesel fuel blends tend to reduce HC emissions when compared to conventional diesel [24]. Diesel

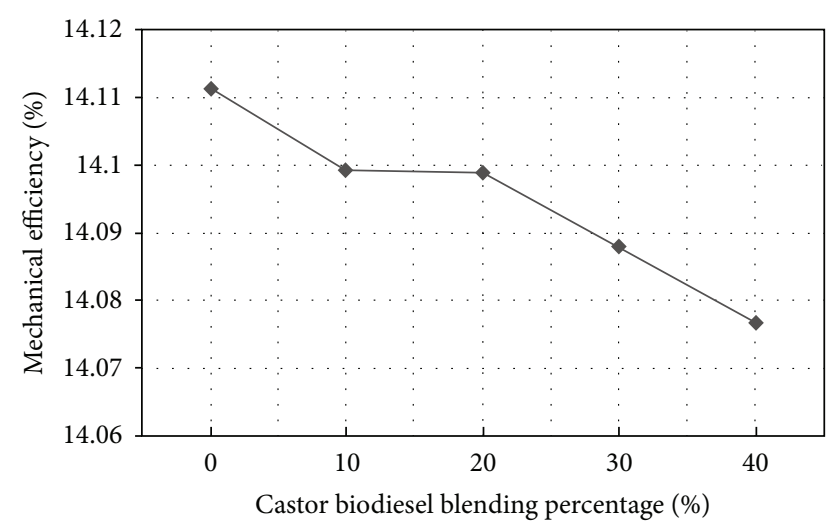

Figure 7: Mechanical efficiency versus castor biodiesel blending percentage.

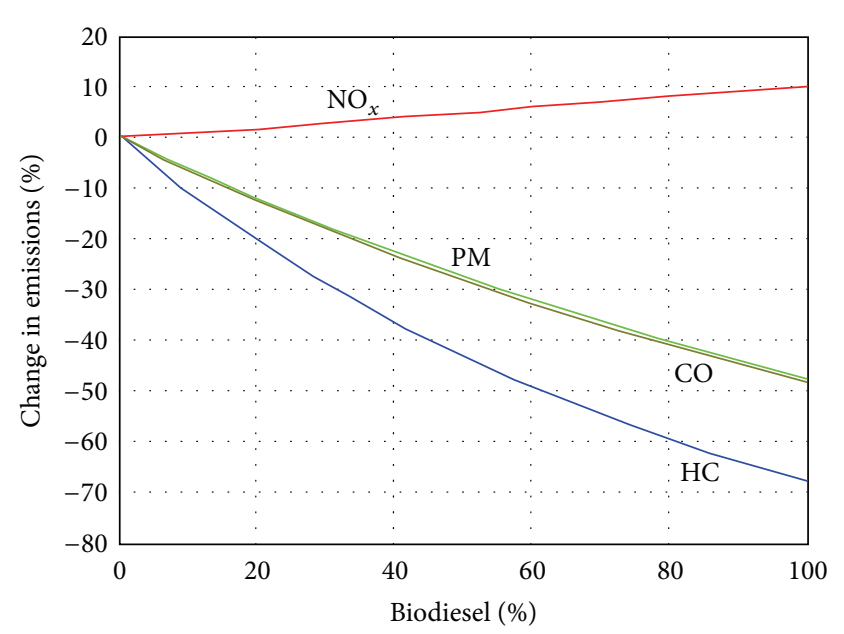

FIGURE 8: Average emission impact of biodiesel for heavy-duty highway engines.

engine performance showed that the biodiesel blend offered lower engine power output, higher specific fuel consumption, and lower mechanical efficiency. Consequently, the biodiesel producing cleaner emission with the significant drop in PM, $\mathrm{CO}$, and $\mathrm{HC}$ emissions compares to the conventional diesel. At any rate, the $\mathrm{NO}_{x}$ still can be reduced with the advanced technologies such as catalytic converter, EGR and engine tuning.

As can be seen from Table 3, B20 is the most suitable biodiesel blend among all. The first criterion is that the engine power output of B20 is not much different from conventional biodiesel where there is only $0.04 \%$ of decrement. Secondly, the specific fuel consumption of B20 is much lower than the $\mathrm{B} 30$ and B40 but slightly the same with B10. In this criterion, B20 is selected, as the SFC is slightly the same with B10, and the higher biodiesel blend produces better combustion. Thirdly, the percentage of decrement in mechanical efficiency of $\mathrm{B} 20$ relative to $\mathrm{B} 0$ is the same as $\mathrm{B} 10$ and not as high as the decrement for B30 and B40. Lastly, the B20 has lower average percentage of change in PM, CO, and HC compared to $\mathrm{B} 10$. Yet, $\mathrm{B} 20$ is producing higher $\mathrm{NO}_{x}$ emission compared 
TABLE 3: The percentage difference for different biodiesel blends relative to conventional diesel, $\mathrm{B} 0$.

\begin{tabular}{lccc}
\hline $\begin{array}{l}\text { Biodiesel } \\
\text { blends }\end{array}$ & $\begin{array}{c}\text { Engine power } \\
\text { output (\%) }\end{array}$ & $\begin{array}{c}\text { Specific fuel } \\
\text { consumption, } \\
\text { SFC (\%) }\end{array}$ & $\begin{array}{c}\text { Mechanical } \\
\text { efficiency (\%) }\end{array}$ \\
\hline B10 & -0.03 & 3.59 & -0.085 \\
B20 & -0.04 & 3.96 & -0.085 \\
B30 & -0.05 & 4.68 & -0.163 \\
B40 & -0.06 & 6.23 & -0.241 \\
\hline
\end{tabular}

The negative sign for biodiesel blends in engine power output and mechanical efficiency is showing the decrement relative to the conventional diesel engine.

to B10. Nevertheless, the B20 is still the suitable biodiesel blend amongst all as the $\mathrm{NO}_{x}$ emission can be reduced with the advanced technologies. Consequently, the B30 and B40 are not recommended as appropriate biodiesel blends due to higher SFC consumption of more fuel to produce $1 \mathrm{KW}$ of power, and lower mechanical efficiency.

\section{Conclusions}

Biodiesel has been successfully produced from the crude castor oil. Biodiesel yield of $93.3 \%$ was achieved using twostep transesterification process. The engine power output is the same as conventional diesel for the B20 blend. Thus, B20 can be selected due to its better combustion with lower average percentage of change in $\mathrm{PM}, \mathrm{CO}$, and $\mathrm{HC}$ emissions compared to conventional diesel.

\section{Conflict of Interests}

The authors declare that there is no conflict of interests regarding the publishing of this paper.

\section{Acknowledgments}

This research work reported in this paper has been funded by the Ministry of Higher Education, Malaysia, under the Research Project FRGS/03(02)/758/2010(44). The study was conducted at the Energy Lab of Department of Mechanical and Manufacturing Engineering, Universiti Malaysia Sarawak, Sarawak, Malaysia, and the authors would like to thank the technicians in the laboratory for their useful contributions in the experimental works.

\section{References}

[1] C. Y. Wei, T. C. Huang, and H. H. Chen, "Biodiesel production using supercritical methanol with carbon dioxide and acetic acid," Journal of Chemistry, vol. 2013, Article ID 789594, 6 pages, 2013.

[2] A. Islam, Y. H. Taufiq-Yap, C.-M. Chu, E.-S. Chan, and P. Ravindra, "Studies on design of heterogeneous catalysts for biodiesel production," Process Safety and Environmental Protection, vol. 91, no. 2, pp. 131-144, 2012.
[3] H. Y. Shrirame, N. L. Panwar, and B. R. Bamniya, "Bio diesel from castor oil-a green energy option," Low Carbon Economy, vol. 2, pp. 1-6, 2011.

[4] A. Murugesan, C. Umarani, R. Subramanian, and N. Nedunchezhian, "Bio-diesel as an alternative fuel for diesel enginesa review," Renewable and Sustainable Energy Reviews, vol. 13, no. 3, pp. 653-662, 2009.

[5] B. K. Barnwal and M. P. Sharma, "Prospects of biodiesel production from vegetable oils in India," Renewable and Sustainable Energy Reviews, vol. 9, no. 4, pp. 363-378, 2005.

[6] M. Belaid, E. Muzenda, G. Mitilene, and M. Mollagee, "Feasibility study for a castor oil extraction plant in South Africa," World Academy of Science, Engineering and Technology, vol. 52, pp. 740-744, 2011.

[7] J. Janaun and N. Ellis, "Perspectives on biodiesel as a sustainable fuel," Renewable and Sustainable Energy Reviews, vol. 14, no. 4, pp. 1312-1320, 2010.

[8] D. P. Deshpande, Y. D. Urunkar, and P. D. Thakare, "Production of biodiesel from castor oil using acid and base catalysts," Research Journal of Chemistry and Environment, vol. 2, pp. 5156, 2012.

[9] F. Ma and M. A. Hanna, "Biodiesel production: a review," Bioresource Technology, vol. 70, no. 1, pp. 1-15, 1999.

[10] M. Kojima, D. Mitchell, and W. Ward, Considering Trade Policies for Liquid Biofuels, World Bank, Energy Sector Management Assistance Program (ESMAP), Washington, DC, USA, 2007.

[11] C. F. Runge and B. Senauer, "How biofuels could starve the poor," Foreign Affairs, vol. 86, no. 3, pp. 41-53, 2007.

[12] H. J. Berchmans and S. Hirata, "Biodiesel production from crude Jatropha curcas L. seed oil with a high content of free fatty acids," Bioresource Technology, vol. 99, no. 6, pp. 1716-1721, 2008.

[13] V. Scholz and J. N. da Silva, "Prospects and risks of the use of castor oil as a fuel," Biomass and Bioenergy, vol. 32, no. 2, pp. 95-100, 2008.

[14] A. Demirbas, "Biodiesel production from vegetable oils via catalytic and non-catalytic supercritical methanol transesterification methods," Progress in Energy and Combustion Science, vol. 31, no. 5-6, pp. 466-487, 2005.

[15] L. Zhu, C. S. Cheung, W. G. Zhang, and Z. Huang, "Combustion, performance and emission characteristics of a di diesel engine fueled with ethanol-biodiesel blends," Fuel, vol. 90, no. 5, pp. 1743-1750, 2011.

[16] D. B. Hulwan and S. V. Joshi, "Performance, emission and combustion characteristic of a multicylinder DI diesel engine running on diesel-ethanol-biodiesel blends of high ethanol content," Applied Energy, vol. 88, no. 12, pp. 5042-5055, 2011.

[17] P. M. Ejikeme, I. D. Anyaogu, C. L. Ejikeme et al., "Catalysis in biodiesel production by transesterification processes-an insight," E-Journal of Chemistry, vol. 7, no. 4, pp. 1120-1132, 2010.

[18] F. E. Soetaredjo, A. Ayucitra, S. Ismadji, and A. L. Maukar, "KOH/bentonite catalysts for transesterification of palm oil to biodiesel," Applied Clay Science, vol. 53, no. 2, pp. 341-346, 2011.

[19] C. C. Enweremadu, H. L. Rutto, and N. Peleowo, "Performance evaluation of a diesel engine fueled with methyl ester of shea butter," World Academy of Science, Engineering and Technology, vol. 79, pp. 142-146, 2011.

[20] A. S. Silitonga, H. C. Ong, T. M. I. Mahlia, H. H. Masjuki, and W. T. Chong, "Characterization and production of Ceiba pentandra biodiesel and its blends," Fuel, vol. 108, pp. 855-858, 2013. 
[21] S. S. V. S. Vinoth, B. R. Diesh, S. A. Elangovan, and S. Srikanth, "Biodiesel from seabuckthorn oil," International Journal of Chemical Engineering Application, vol. 2, pp. 15-18, 2010.

[22] A. S. Ramadhas, C. Muraleedharan, and S. Jayaraj, "Performance and emission evaluation of a diesel engine fueled with methyl esters of rubber seed oil," Renewable Energy, vol. 30, no. 12, pp. 1789-1800, 2005.

[23] D. Y. C. Leung, "Development of a clean biodiesel fuel in Hong Kong using recycled oil," Water, Air, and Soil Pollution, vol. 130, no. 1-4, pp. 277-282, 2001.

[24] C. C. Enweremadu and M. M. Mbarawa, "Technical aspects of production and analysis of biodiesel from used cooking oil-a review," Renewable and Sustainable Energy Reviews, vol. 13, no. 9, pp. 2205-2224, 2009.

[25] M. A. Fazal, A. S. M. A. Haseeb, and H. H. Masjuki, "Biodiesel feasibility study: an evaluation of material compatibility; performance; emission and engine durability," Renewable and Sustainable Energy Reviews, vol. 15, no. 2, pp. 1314-1324, 2011. 

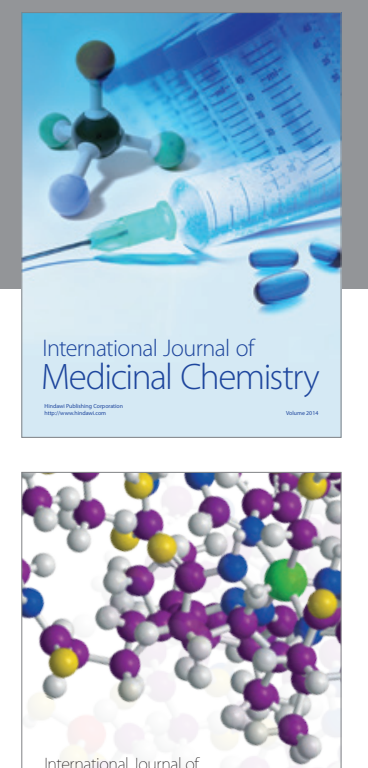

\section{Carbohydrate} Chemistry

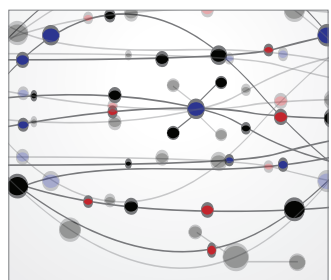

The Scientific World Journal
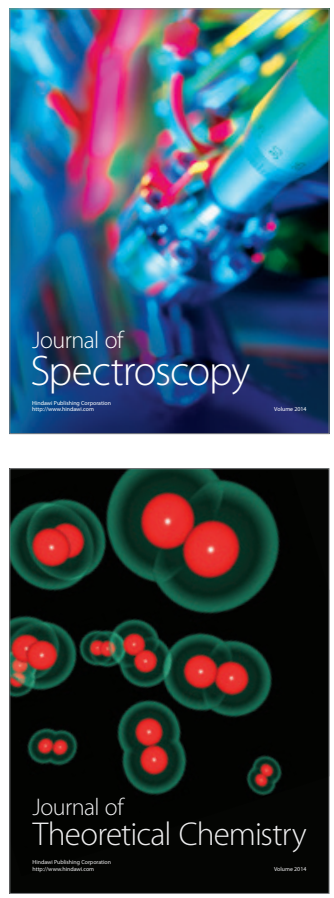
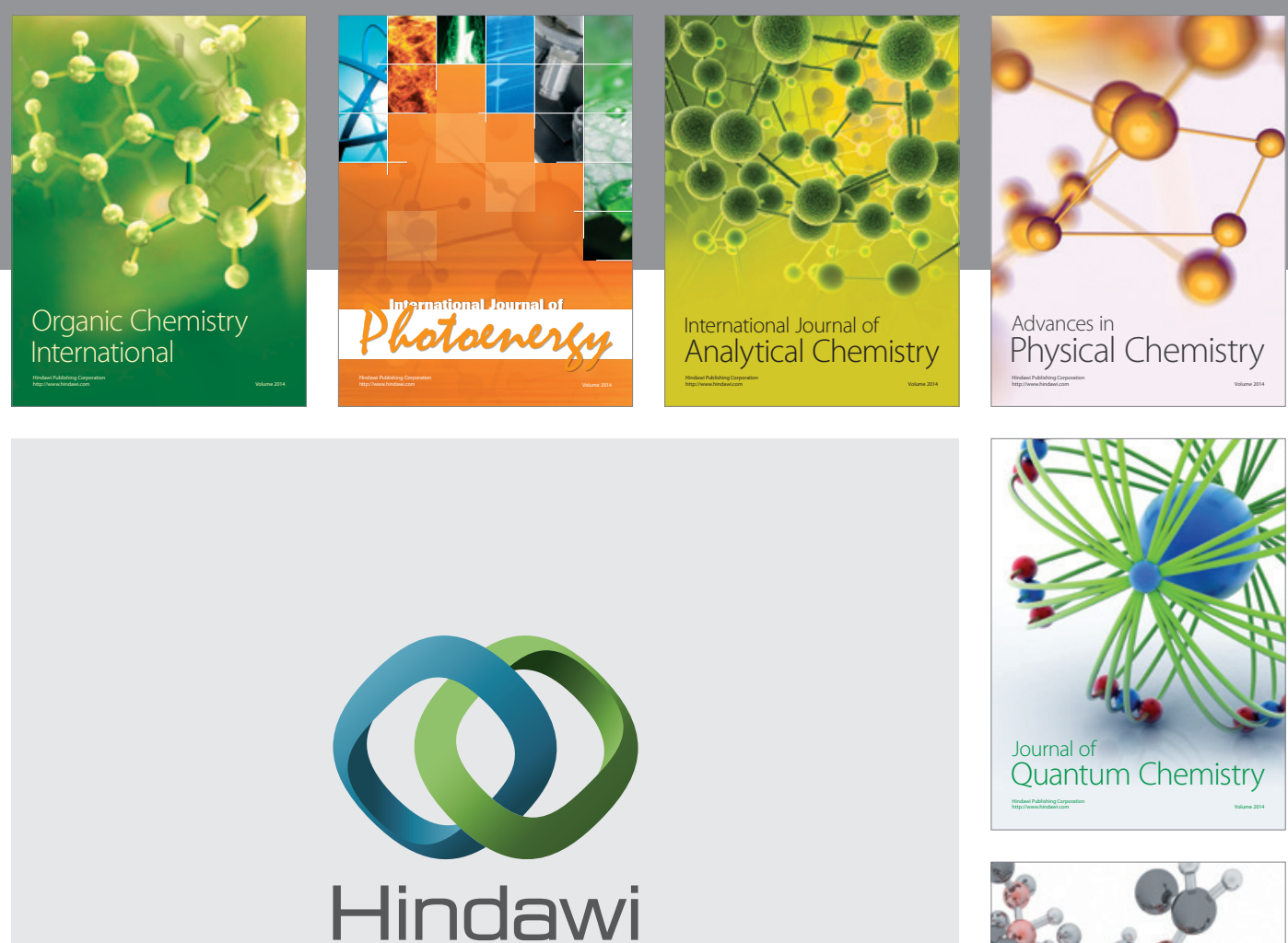

Submit your manuscripts at

http://www.hindawi.com

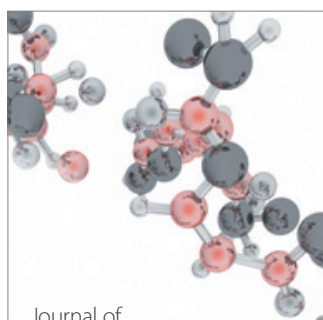

Analytical Methods

in Chemistry

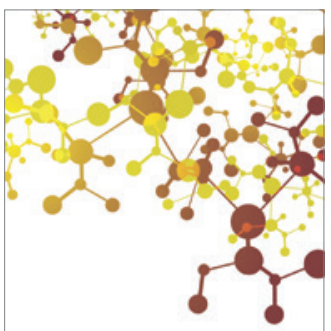

Journal of

Applied Chemistry

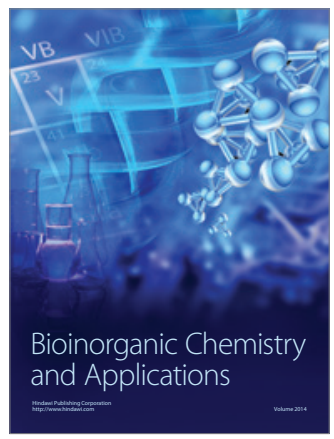

Inorganic Chemistry
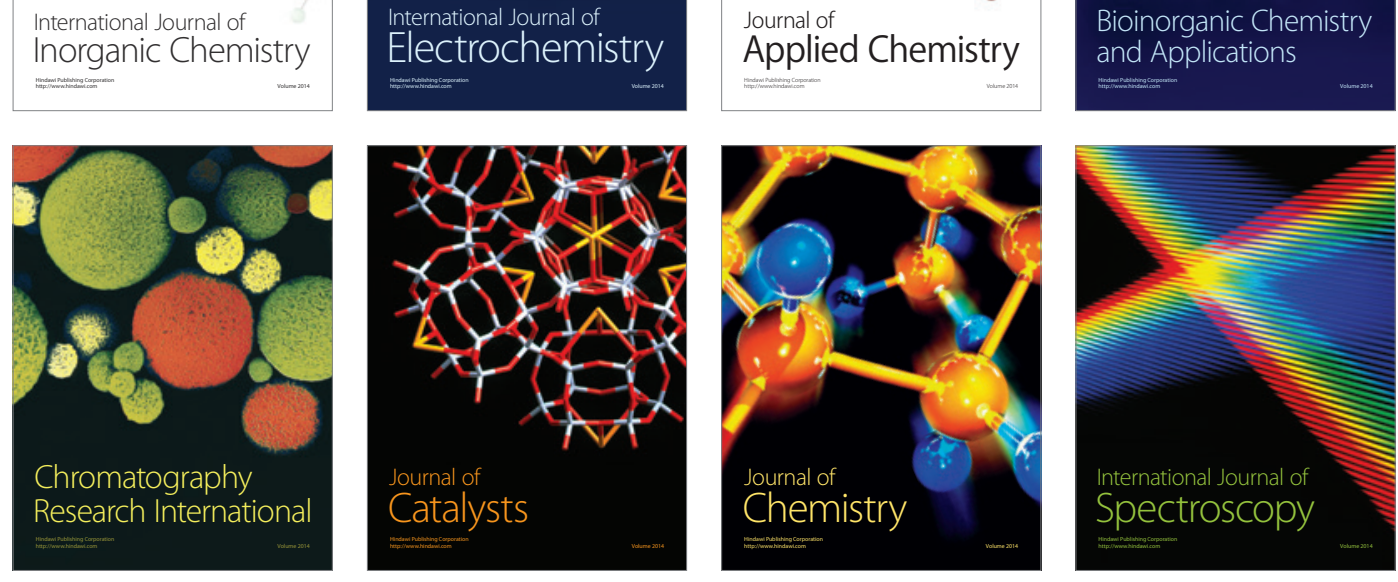